The text deliberately is not supported by concrete evidence, or references to detailed studies, so that the treatment of complex problems in cell structure and function becomes too superficial to be as useful as it could be.

JOSEPH ChAYEN cessors. It will be indispensable to immunologists and geneticists interested in the control and variation of protein synthesis. Despite the rapidity of progress in the biological sciences, its contents will remain essential reading.

L. E. GLYNN

\section{Surveys and Symposia}

Cold Spring Harbor Symposia on Quantitative Biology. Vol. XXXII. Antibodies. Edited by Leonora Frisch. (Pp. xix +619 ; illustrated + tables. \$20.00.) New York: Cold Spring Harbor Laboratory of Quantitative Biology. 1968.

The nature of immunological specificity has been and still is the central problem of immunology, and now that direct template theories of antibody synthesis are no longer tenable interest has focused upon the primary structure of antibodies, i.e. the amino acid sequence of their constituent polypeptide chains. Since, according to the current teaching of molecular biology, this sequence is determined by the base sequence of the corresponding gene, and since the number of specifically distinct antibodies capable of synthesis by a single individual may be several thousands or even tens of thousands, it must be conceded that this enormous number of genes coding for a single class of proteins is available in every normal antibody-producing animal. The manner in which this phenomenal genetic potentiality is achieved is of fundamental interest to both immunologists and geneticists, and formed the central theme of the symposium on antibodies, being the thirty-second symposium on quantitative biology held at Cold Spring Harbor in June 1967.

The majority of the participants support some form of clonal selection by antigen, as first put forward by Burnet. This requires a truly remarkable degree of somatic mutation to provide the necessary variety of stem cells each capable of reacting to a different antigenic pattern. Of the several hypotheses discussed, the one presented by Smithies seems to cover the widest range of observed facts with the minimum of assumptions. It postulates the control of the variable part of the antibody light chain by a gene pair consisting of a master gene and a scrambler gene. Crossing-over between these two genes can then give rise to the variability in amino acid sequence as observed in the structure of these peptide chains.

A further aspect of immunology of especial interest to geneticists is the large number of genetically determined allotypes in which the immunoglobulins appear. These allotypes, usually dependent upon single amino acid substitutions, affect both the heavy and light chains of the whole immunoglobulin molecule. The subject received detailed attention by many of the speakers.

The standard of the communications at this symposium achieved the high level established by its prede-
Histo- und Zytogenese der sich entwickelnden Retina: Eine elektronenmikroskopische Studie. By Karl Meller. (Pp. viii + 77; 47 figures. DM.21.) Stuttgart: Gustav Fischer Verlag. 1968.

This small and carefully detailed monograph deals with the histogenesis and cytogenesis of the developing retina of the chick. It follows the differentiation of the primitive ectodermal cells (the germinal cells) into the many cell types that comprise the adult eye. Special emphasis is given to the Müller cells-the neuroglia of the retina-but every cell type is described both as to its structure and its origin. The electron micrographs are of a high standard and are clearly labelled. The ultrastructure is frequently clarified by comparison with retina prepared by the conventional Golgi method. This very neat monograph is completed by a useful bibliography.

Kraniofaziale Dysplasien und Störungen der Zahnentwicklung Experimentelle und vergleichende Untersuchungen. By W. Ritter. (Pp. $x i+112$; illustrated + tables. $D M$ 35.) Stuttgart: Gustav Fischer Verlag. 1968.

This is a detailed account of the malformations seen in 2055 newborn mice belonging to 4 different strains and derived from litters exposed to a single dose of radiation to the head-anlage at various successive states of pregnancy. Special attention was paid to the anomalies of the lower jaw and teeth, as earlier teratological investigations appeared to stress craniofacial rather than mandibular defects. Radiation was found most effective when applied on the 7th or 8th day of embryonic life. The genetic basis of these induced anomalies was shown by the fact that there were striking differences in the frequency of $x$-ray induced malformations in the 4 strains studied. In one strain in which mandibular hypoplasia occurred spontaneously in some $5 \%$ of offspring, the incidence rose to $43 \%$ after irradiation. The deformities observed fell into two main types, one being arrhinencephaly-cyclopia and the other craniofacial otocephalic. When deformities of tooth germ occurred, the whole of the germ tended to be involved, probably because of spatial relationship.

There is a useful survey of the literature and a discussion on analogous human anomalies which show a rather less complete group of variations than is seen in the experimental material. 